\title{
A D-vitamin-pótlás jelentősége a gyakoribb, időskori poroticus törésekben
}

\author{
DR. SALAMON ANTAL'1, DR. BIRÓ CSABA', DR. SÁNDOR ZOLTÁN', \\ DR. SZILÁGYI ZOLTÁN', DR. TOLDY ERZSÉBET ${ }^{2}$
}

\section{ÖSSZEFOGLALÁS}

Az időskori osteoporoticus törések száma világszerte növekszik. A porosisos csontszerkezet meggyengül, a csonttörés eleséskor, vagy akár kisebb erőhatásra is bekövetkezik. Főként a csípőtáji, distalis radius-, proximalis humerus-, és csigolyatörések fordulnak elő a leggyakrabban. A törések keletkezésekor fontos tényező a D-vitamin-hiány is, amely az idős emberek jelentős részét érinti. Ismert tény, hogy az osteoporoticus emberek közel 70\%-a D-vitamin-hiányos és ezzel együtt kalciumellátottsága sem megfelelő. A rehabilitációra szoruló idős emberek többsége különösen súlyos D-vitamin-hiányban szenved. Ezzel összefüggésben az ilyen betegek izomereje gyengül, járóképességük romlik, ennek következtében mozgásukban korlátozottak, fizikai aktivitásuk csökken. Ezért, úgy a meglévő csonttömeg megtartásában, mint a törések megelőzésében, illetve a törést elszenvedettek gondozásában fontos tényező a D-vitamin- és kalciumpótlás. A közlemény célja, hogy felhívja az ilyen sérültek ellátását végző orvosok figyelmét arra, hogy célszerú tájékozódni a betegek D-vitamin- és kalciumellátottságáról, szükség esetén a pótlásról gondoskodni, amit az elbocsátott betegnek otthonában is érdemes tovább folytatni. Ezzel várhatóan javítható a betegek további életkilátása és életminősége.

\section{Kulcsszavak: $\quad$ Elesés, Csonttörés; D-vitamin-pótlás; Időskor; Kalciumpótlás; Osteoporosis; Táplálék kiegészítők;}

A. Salamon, Cs. Biró, Z. Sándor, Z. Szilágyi, E. Toldy: The importance of vitamin D supplementation in the more frequent elderly osteoporotic fractures

With aging population the number of osteoporotic fractures is growing throughout the world. The porotic bone is characterised by low bone mass and increased fragility. The cause of fracture can be resulted by falling or just by minor trauma. Mainly the hip, distal radius, proximal humerus and vertebral fractures are frequent. Vitamin D deficiency is an important factor which affects great part of the old population. It is well known that $70 \%$ of the osteoporotic people suffer from vitamin D deficiency and their calcium supply is not adequate. The majority of old people who need rehabilitation suffer from serious vitamin D deficiency. In correlation with this their muscle strength becomes weaker, the walking capacity, physical activity decreases. Consequently it is very important to perform vitamin $\mathrm{D}$ and calcium substitution. The aim of our article is to pay attention to this statement of physicians who are dealing with these patients that is important to inquire about the vitamin $D$ and calcium status. If it is necessary the substitution can be continued at home. These way patients will have better future chances and quality of life.

Keywords: $\quad$ Accidental falls - Prevention \& control; Aged;

Calcium, dietary - Therapeutic use; Dietary supplements;

Fractures, bone - Prevention \& control;

Osteoporotic fractures - Prevention \& control; Vitamin D - Therapeutic use; 


\section{BEVEZETÉS}

$\mathrm{Az}$ osteoporosis napjainkban az egyik leggyakoribb megbetegedés, a hazai populációban közel 800 ezer beteget érint, a nő-férfi arány 3:1 (26). Az osteoporosis a csontváz generalizált betegsége, amely törési rizikóval jár. Patogenezisében szerepet játszó faktorok közül a genetikus tényezőké (50-80\%) a fő szerep, de a menopauza, életkor, étkezési és életvitelbeli szokások is meghatározóak. A betegek száma világszerte emelkedik. A csontszerkezet gyengülése együtt jár a csont törékenységének a megnövekedésével. Az idős emberekben a szexuálszteroid (ösztrogén, tesztoszteron) szintek csökkenése miatt a remodelling szakaszban az életkor növekedésével csökken a csonttömeg. Ehhez a folyamathoz társul hozzá a mozgásszegény életmód. A D-vitamin-hiány idősebb emberek körében sokkal gyakoribb, különösen a rehabilitációra szoruló idős betegek többsége szenved súlyos D-vitaminhiányban. A bőrben a napsugár hatására nagyságrendekkel több $D_{3}$-vitamin keletkezik, mint amennyit a hazai átlagos táplálkozással a szervezetbe vihetünk. Viszont az idős, mozgáskorlátozott ember esetében a szezonális UVB fényviszonyoktól függetlenül kell felmérnünk a D-vitamin-ellátottságot. A nem megfelelő táplálkozás, a kevés tejtermék fogyasztása a kalcium elégtelen beviteléhez vezet. $\mathrm{Ha}$ a D-vitamin-ellátottság elégtelen, akkor a parathormon intact (PTHi) szint megemelkedik, ami csontmátrixból kalciumot mobilizál, így csonttömeg-vesztés alakul ki. A D-vitaminnak a több extraskeletalis hatása közül az egyik az izomerő növelése. Hiány esetén az izomerő csökkenése miatt a betegek járása bizonytalanná válik, növekszik az elesés valószínűsége, a csonttörés rizikója is $(40,42,45,47)$.

$A$ jelen állásfoglalás szerint a szérum 25(OH)D szint a legmegbízhatóbb markere a D-vitamin-ellátottságnak, mert biológiai félélet ideje az összes metabolit közül a leghoszszabb (15-35 nap), valamint a májban lezajló 25-hydroxiláció nagy kapacitású, elsősorban a szervezetben előforduló összes D-vitamin mennyiségétől függ. A jelenleg érvényben lévő konszenzusok a 25(OH)D szintek alapján definiálják a D-vitamin-ellátottság kategóriáit, amelyek az I. táblázatban olvashatók (45). Mivel idős korban gyakoriak az egyéb társuló betegségek is, amelyek önmagukban is megváltoztathatják a D-vitamin metabolizmusát, ezért a $25(\mathrm{OH}) \mathrm{D}$ szint értékelésekor ezeket is figyelembe kell venni. A megfelelő D-vitaminellátottság javíthatja az izomfunkciót, a csont megújulását, a kognitív funkciót és legtöbb esetben a társuló alapbetegség remissziójának kedvez, így fontos szerepet játszhat a törések prevenciójában.

Egy nagyobb esetszámú utánkövetéses vizsgálattal bizonyítást nyert, hogy a tartósan alacsony $25(\mathrm{OH}) \mathrm{D}$ szinttel $(<50 \mathrm{nmol} / \mathrm{L})$ rendelkező idős nők esetében az osteoporoticus csonttörés bekövetkeztének rizikója kétszer nagyobb $(p<0,001)$, mint a magas $25(\mathrm{OH}) \mathrm{D}$ szinttel (>75 nmol/L) rendelkezőké (8). Napjainkban elfogadott tény, hogy az osteoporosis kezelésekor a specifikus antireszorptív terápia mellett $D_{3}$-vitamin és kalcium adása is történik, amelynek elsődleges célja a primer törés prevenciója (33). A spongiosus csontok törnek el leggyakrabban, így a distalis radiustörések, csípőtáji törések, proximalis felkarcsont- és csigolyatörések fordulnak elő elsősorban. A már törést szenvedett betegek utánkövetése különös figyelmet érdemel, mert a korábbi törés önmagában akár többszörös törési kockázatot rejt magában, így ők nagyobb veszélyben vannak. Ennek ellenére csak közel 20\%-uk részesül hosszú távú és hatékony csontritkulás elleni kezelésben (44). Fischer és munkatársai (13) által írt áttekintő közleményükben a kalcium és D-vitamin együttes adását követően vizsgálták a poroticus csonttörések gyógyulását és a poszttraumás csontok turnoverét. Hangsúlyozzák, hogy az osteoporosis kihat a csont regeneratív kapacitására is, és ezért okozhatnak komplikációkat a törés utáni gyógyulásban. A D-vitamin és kalcium együttes adására a hatékonyabb gyógyulási tapasztalatot a 12 experimentális - főként patkányokon végzett tanulmányból 8-ban igazolták. Egy randomizált placebo kontrollált klinikai tanulmányban idős, törést szenvedett nőkön vizsgálták a $D_{3}$-vitamin és a kalcium hatását a callus képződésre és a funkcionális gyógyulására. Mindkettőre nézve a kuratív hatás igazolódott (13). Ezek az eredmények alátámasztják a kalcium és $D_{3}$-vitamin terápiás hatását a törés ellátását követően is, indokolttá téve a vitaminhiányos és osteoporoticus betegek szubsztitúcióját.

Közleményünk megírásának célja, hogy 
áttekintést adjunk a fenti spongiosus csonttörésekkel és a $D$-vitamin-pótlással kapcsolatos irodalmi adatokról, valamint, hogy felhívjuk az ilyen sérültek ellátását végző orvosok figyelmét arra, hogy a törések ellátásánál célszerű tájékozódni a betegek életvitelbeli, étkezési szokásairól, D-vitamin- és kalciumellátottságáról, és egyéb olyan krónikus betegségükről, amelyek kihatnak a D-vitamin metabolizmusára. Szükséges mennyiségben gondoskodjanak a pótlásról, amit az elbocsátott betegnek otthonában is célszerű tovább folytatni, ezzel is javítva a betegek további életkilátásait és életminőségét.

\section{CSÍPÖTÁJI TÖRÉSEK}

A D-vitamin-hiány és a csípőtáji törések közötti kapcsolatról áll rendelkezésre a legtöbb irodalmi adat $(2,21,22,30,32,35-38,46$, 47). Nem véletlen, hisz gyakoriságát tekintve a világon az osteoporoticus törések közül 1,6 millió/év fordul elő, ezt a radiustörés csak 0,1 millióval előzi meg (19). Hazánkban, 2004-ben Lakatos és munkatársai (20) 17992, míg Flóris és munkatársai (14) 13093 csípőtáji törött esetet regisztráltak, a felmérésük nem ugyanazon adatbázisból történt. Számuk további növekedése várható évről-évre úgy hazánkban, mint világszerte, az öregedő társadalmakban. A törések incidenciájának növekedését a magasabb életkorral járó mozgáskorlátozottság során kialakuló fokozott csontállományvesztés okozza. Jelentős tényezőként említendő az esetek többségében meglévő D-vitamin-hiány, a csekély kalciumbevitel, amelyek fokozzák a csonttömeg csökkenését. A csípőtáji törések előfordulása mellett a társuló krónikus betegségek és az ezzel járó több mint 4-5-féle gyógyszer egyidejű szedése ugyancsak jelentősek (26), saját tapasztalatunkban a betegeink közül csak $13 \%$ volt mentes krónikus betegségtől (49).

A törés bekövetkeztét okozó elesések szerepével többen foglalkoznak. A 65 éven felüli emberek közel egyharmada, 80 éven felül pedig majdnem 50\%-uk elesik évente legalább egyszer (47). Mészáros (25) szerint a D-vitamin-hiányban kialakuló sarcopenia miatt a járás bizonytalanná válik és az elesés könnyen bekövetkezik. Bischoff Ferrari és munkatársai (5) szerint a megfelelő 25(OH)D szint csökkenti az elesések számát és növeli a csont denzitását, így csökkenti a törési rizikót. Mások közleményükben azt írják, hogy fontos az izomzat jó állapota, a megfelelő 25(OH)D szint elérése az elesések megelőzésében. Vizsgálataik szerint a D-vitamin az elesések számát 19\%-kal, a csípőtáji törések számát 18\%-kal csökkenti. $\mathrm{Az}$ elesések prevenciója legalább $700 \mathrm{NE} /$ nap $D_{3}$-vitamin adásával lehet sikeres (4). Di Monaco és munkatársai (9) hangsúlyozzák, hogy az alacsony 25(OH)D szint rontja az alsó végtag funkcióját, növeli az elesések és törések számát, de meg kell jegyezni, hogy a $25(\mathrm{OH})$ D-vitamin-szint és az elesések valószínűsége között több ellentmondásos metaanalízis is megjelent. Murad és munkatársai (27) a kalciummal adott D3-vitamin csökkenti az esések bekövetkeztét, míg Bolland és munkatársai (6) azt találták, hogy a $D_{3}$-vitamint kalciummal, vagy a nélkül adva, egyik sem csökkentette 15\%-nál jobban az elesések számát. Egy másik randomizált kontrollált vizsgálat $D_{3}$-vitamin adagolástól függően vizsgálta a kérdést, és azt tapasztalták, hogy a nagyobb dózisok adása esetén az elesések száma nőtt, szemben az alacsonyabb egységek adása esetén (3).

Buchebner és munkatársai (8) vizsgálatai szerint nagyszámú idős svéd nő osteoporosis talaján kialakult csípőtáji törések szignifikánsan nagyobb számban fordult elő a rossz D-vitaminellátottságú nőkben, mint ahogy azt az átlagpopulációban észlelték. Ha a D-vitamin-hiányos állapotuk több mint 5 évig fennállt, akkor a 10 éven belüli osteoporoticus csonttörés rizikó jelentősen nőtt.

A metaanalízisek a $D_{3}$-vitamin és a csonttörések megelőzése között eltérő konklúzióra

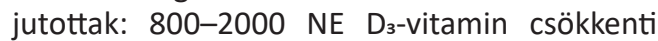
a non-vertebralis törések bekövetkeztét (5). Mások szerint csak a kalciummal együtt adott $D_{3}$-vitamin csökkenti a törési rizikót (1), de csak az öregek otthonában élő idősek körében, nem az otthonukban élő idősekben (6). Lv és munkatársai (23) metaanalízisükben a szérum 25(OH)D és a csípőtáji törések rizikójának kapcsolatával foglalkozik. Következtetésük szerint az alacsony $25(\mathrm{OH}) \mathrm{D}$ szint növeli a törések rizikóját és ennek cutoff értékét $<60 \mathrm{nmol} / \mathrm{L}$-ben jelöli meg.

Saját megfigyelésünk során 203 csípőtáji töréssel operált betegünk esetében azt találtuk, hogy akiknek felvételkor magasabb volt 
a 25(OH)D szintje, a mútét utáni korai javulásuk szignifikánsan jobb volt, mint az alacsonyabb 25(OH)D szintű eseteké, akik nehezen voltak mobilizálhatóak. Ez a megfigyelésünk független volt a betegek társuló alapbetegségeitől (36, 49). Ismert tény, hogy a mútétet követően a betegek gyógyulási esélye, korábbi funkcionális állapotuk visszanyerése ritkán sikeres (38). Folman és munkatársai (15) szerint csak közel 17\%-a nyeri vissza az eredeti funkcionális állapotát, életminőségük romlik, többségük rehabilitációra, intézményben való elhelyezésre szorul, ami az egészségügyi ellátórendszert rendkívül megterheli.

Ami a csípőtáji mútéten átesettek túlélési esélyeit illeti, a közölt adatok szerint az esetek 12-36\%-a hal meg a mútétet követő 1 éven belül, de ezután a mortalitásuk már nem tér el az azonos korú lakosságéhoz képest (20, 39, 48). Saját betegeink esetében a mútét utáni 7 hónap után végzett követéses felmérés és elemzés során a betegek mortalitási rátája $15,6 \%$ volt. Az életkorra és a társuló súlyos betegségre kontrollálva a kumulatív túlélési időt azoknak, akiknek magasabb volt az összes keringő 25(OH)D szintje szignifikánsan jobb túlélése volt (8). A fentiek alapján kijelenthető, hogy a csípőtáji törötteknél a D-vitamin státusz, a mútét utáni állapot és a 25(OH)D szintek közötti összefüggés megerősíti a D-vitamin-szint fenntartásának vagy pótlásának a fontosságát, úgy a törés megelőzésében, mint a gyógyulásában és a túlélésben is $(36,37,49)$. Jóllehet, a kezdeti adatok felhívják a figyelmet arra is, hogy a megfelelő $25(\mathrm{OH}) \mathrm{D}$ szint ismerete minden klinikai helyzetben még nem definiált.

$A z$ irodalomban a csípótáji törések során adható D-vitamin-pótlást illetően két álláspont kristályosodott ki. Egyesek 800-1000 NE/nap $D_{3}$-vitamin adását javasolják, míg mások a D-vitamin és 1000-1500 mg kalcium együttes adását tartják szükségesnek. Annak eldöntésére, hogy miként járjunk el, mérlegelni kell az idős betegek táplálkozási szokásait, a társuló cardiovascularis vagy más krónikus betegségek meglétét, mert ezek a körülmények befolyásolhatják a D-vitamin metabolizmusát (I. táblázat). Részletes adatok e téren a közelmúltban megjelent közleményünkben találhatók (37).

I. táblázat Javasolt D-vitamin- és kalciumpótlás a társuló klinikai állapotok figyelembevételével

\begin{tabular}{|c|c|c|}
\hline Ajánlott napi adagok & $\begin{array}{l}\text { Pontos dózis megállapításakor } \\
\text { mérlegelendő szempontok }\end{array}$ & $\begin{array}{l}\text { D-vitamin-ellátottság } \\
\text { kategóriái a szérum } \\
\text { 25(OH)D* szintek alapján }\end{array}$ \\
\hline $\begin{array}{l}\text { D3-vitamin } \\
\text { 800-1000 NE/nap }\end{array}$ & $\begin{array}{l}\text { Ellenjavallt: } \\
\text { - granulomatosusos megbetegedés } \\
\text { (sarcoidosis) } \\
\text { - hypercalcaemia }\end{array}$ & $\begin{array}{l}\text { súlyos hiány: } 10-15 \mathrm{nmol} / \mathrm{L} ; \\
\text { enyhe hiány: } 16-20 \mathrm{nmol} / \mathrm{L} ; \\
\text { hiány: } 20-50 \mathrm{nmol} / \mathrm{L} ; \\
\text { elégtelen: } 50-75 \mathrm{nmol} / \mathrm{L} ; \\
\text { elégséges: }>75 \mathrm{nmol} / \mathrm{L}\end{array}$ \\
\hline $\begin{array}{l}\text { Kalcium } \\
\text { 1000-1500 mg/nap }\end{array}$ & $\begin{array}{l}\text { - mennyisége a diétával bevitt } \\
\text { kalciumtól függ } \\
\text { - Ca-karbonát készítmény idült } \\
\text { gastrointestinalis tünetek, **PPI- } \\
\text { szedők esetén nem javallt, helyette } \\
\text { Ca-citrát adása javasolt. } \\
\text { Adása megfontolandó: } \\
\text { - fokozott cardiovascularis kockázat } \\
\text { (1000-1200 mg/nap adagnak nincs } \\
\text { előnytelen hatása) } \\
\text { - ismert vesekövesség esetén }\end{array}$ & \\
\hline
\end{tabular}

*25(OH)D: 25-hidroxi-D-vitamin, átváltási faktor: $1 \mathrm{ng} / \mathrm{ml}=2,5 \mathrm{nmol} / \mathrm{L}$

**PPI: protonpumpa inhibitor 


\section{DISTALIS RADIUSTÖRÉSEK}

A distalis radiustörések általában alacsonyabb életkorban következnek be, mint a combnyaktörések, amelyek főleg postmenopausalis nők esetében gyakoriak. A leggyakoribb törésként vannak számon tartva, kórokként az osteoporosis és a D-vitaminhiány is áll, kisebb traumára is létrejöhetnek (43). Az elesés során általában a védekező kitámasztó kéz ütközése során következik be a törés. Rozental és munkatársai (34) hangsúlyozzák a radius ezen spongiosus részének a fokozott törékenységét. Véleményük szerint a D-vitamin-hiány és a fokozott csont-turnover nagyfokú csontveszteséggel jár. Azt találták, hogy a distalis radiustörések esetében alacsonyabbak a szérum 25(OH)D szintek. A D-vitamin szerepéről fontos adatok találhatók Jang és munkatársai (18) közleményében. 104 postmenopauzában lévő beteg mútéttel kezelt distalis radius töröttet és 107 törés nélküli hasonló életkorú nőt vizsgáltak. A törött csoportban a $25(\mathrm{OH}) \mathrm{D}$ szint szignifikánsan alacsonyabbnak bizonyult a kontrollcsoporthoz viszonyítva. A csont ásványi anyag tartalma (BMD) ugyancsak szignifikánsan alacsonyabb volt, míg a PTHi értékek emelkedtek. Tahririan és munkatársai (43) szignifikáns összefüggést találtak a distalis radius törött betegek BMD és 25(OH)D szintje között. Véleményük szerint D-vitamin-pótlással a $65-70$ éves nőkön végzendő hasonló vizsgálatok jó prevenciót jelentenének a jövőben fenyegető törések (pl. csípőtáji) számának csökkentésére. Péntek és munkatársai (31) szerint a distalis radius töröttek 55\%-a 10 éven belül, $80 \%$-a 20 éven belül újra csonttörést szenved el. Ennek ismeretében a csípőtáji törés várható bekövetkezése előtt már megelőző terápiát lehetne kezdeni D-vitamin adással. A fenti típusú osteoporoticus törések bekövetkezésére mintegy $40 \%$ esélye van az időskorú betegeknek. Oven és munkatársai (29) szerint a kis traumára bekövetkező distalis radiustörés bekövetkeztének esélye a nők esetében, ha a szérum $25(\mathrm{OH}) \mathrm{D}$ szintek $<50 \mathrm{nmol} / \mathrm{L}(\mathrm{OR}=2,3)$, míg az esély lecsökken $(\mathrm{OR}=1,7)$, ha a $25(\mathrm{OH})$ D-vitamin-szint 50-75 nmol/L között volt. Dua és munkatársai (12) postmenopausalis nők esetében vizsgálták a percután $\mathrm{K}$-Wire fixációval kezelt esetek kézszorító képességét. Azoknak, akiknek a 25(OH)D szintjük megfelelő volt, a szorító erejűk szignifikánsan nagyobb volt, az elégtelen D-vitamin-ellátottságú ( $<75 \mathrm{nmol} / \mathrm{L})$ csoporthoz képest.

\section{PROXIMALIS HUMERUSTÖRÉSEK}

E téren kevesebb irodalmi adat áll rendelkezésre. A proximalis humerustörések többsége is idős korban következik be. Az ilyen egyének már nem tudják a megfelelő védekező reflexek hiánya miatt kivédeni a közvetlenül válltájat ért ütéseket, s akár kisebb erőbehatásra is csonttörést szenvednek el. A kialakult funkciózavar megnehezíti a beteg tisztálkodását, étkezését (40). Doetsch és munkatársai (10) vizsgálták az osteoporoticus proximalis humerustörések után kialakuló callus képződést. BMD scanning vizsgálatokat végeztek. Az naponként alkalmazott 800 NE D-vitamin és $1 \mathrm{~g}$ kalcium kezelés pozitív hatását észlelték 6 hét után. Konklúziójuk az volt, hogy ezzel a kezeléssel javítani lehet a callus képződést.

\section{VERTEBRALIS (CSIGOLYATEST) TÖRÉSEK}

A rendszerint spontán, vagy csak kis traumára bekövetkező csigolyatest törések fóleg időskorban az osteoporoticus csigolyákon következnek be. Fájdalommal járnak, de néha tünetmentesek, s csak később kerülnek észlelésre. Egy, vagy néha több csigolyatest törik el, s inkább az alsó thoracalis vagy lumbalis szakasz érintett. Dorner és munkatársai (11) szerint a csigolyatörések gyakoribbak az USA-ban és Európában a 60 év feletti nőknél, mint a férfiaknál. Ez a már kialakult osteoporosisnak tulajdonítható. A csigolyatest törések után a nők halálozási rizikója 66\%-kal megnő az átlagpopulációhoz viszonyítva (40). A csigolyatest törésekre jellemző lehet a fájdalom, deformitás, magasságvesztés. A törések kialakulásában jelentős szerepe van a D-vitamin-hiánynak. Maier és munkatársai (24) 246 átlagosan 69 éves csigolyatest törött betegnél mérték a 25(OH)D szinteket, s kontrollként 392 hátfájós, de nem törött esetet vizsgáltak. A csigolyatörött esetekben szignifikánsan alacsonyabb volt a D-vitamin szint. Hernandez és munkatársai (17) azt találták, hogy a törések megnövekedett gyakorisága emelkedett PTHi szintekkel társult, alacsony BMD vagy magasabb csont-turnover 
markerek (BTMs) csak elégtelen D-vitamin-ellátottságban voltak észlelhetők.

Más adatok szerint a romló életminőség nagy problémát jelent az idős, osteoporoticus csigolyatestű nőknél. Ohta és munkatársai (28) 1585 osteoporoticus nőnél vizsgálták a testtömeg indexet, a BMD-t és a szérum $25(\mathrm{OH})$ $D$ értékeket. Véleményük szerint az alacsony 25(OH)D szint szignifikánsan határozza meg az életminőséget a csontritkulásos nőkben, függetlenül más konvencionális faktoroktól. A magasabb, mint $50 \mathrm{nmol} / \mathrm{L}$ szint hivatott fenntartani az osteoporoticus betegek jobb életminőségét. Gomez de Tejada és munkatársai (16) 1229 csigolyatörött, menopausalis nőt kezeltek, akiknek 37.7\%-a vidéki falusi környezetben, 68.5\%-a városokban élt. A falusi környezetben élők szérum 25(OH)D-vitamin szintje alacsonyabb volt. Ezeknél a gerinc lumbalis szakaszában mért BMD értékek ugyancsak alacsonyak voltak, a csigolyatest törések száma gyakoribb volt, közöttük többen túlsúlyosak, hypertoniásak és diabetesesek voltak. Avenell és munkatársai (1) által írt metaanalízis szerint az orálisan adott kalcium önállóan is csökkenti a vertebralis törések számát.

\section{MEGBESZÉLÉS}

Az osteoporosis talaján létrejövő törések az idős életkor emelkedésével egyre gyakrabban fordulnak elő, s a felmerülő problémával sok irodalmi adat foglalkozik. A törések gyakran vezetnek az életminőség romlásához a beteg független életmódjának elvesztéséhez, funkciózavarokhoz, s megnövekedett morbiditással, mortalitással, kezelési költségekkel járnak. A lakosság életkorának további emelkedése miatt az ilyen törések - főleg a csípőtáji törések száma - várhatóan tovább fog emelkedni. 2000-ben világszerte 9 millió osteoporoticus csonttörés fordult elő, melyekből 1,6 millió volt a csípőtáji törés, 1,1 millió a distalis radius törés és 1.4 millió a csigolyatest törés (11). Sebestyén és Somogyi (40) szerint egy 50 éves nőnek élete további részében $17.5 \%$ esélye van csípőtáji, 15,6\% csigolyatest törésre, és $16 \%$ distalis radiustörésre. Férfiaknál a kockázat ennek 1/3-a. A csigolyatest törés esetén 4-szer nagyobb esély van egy újabb törés bekövetkezésére. A distalis radiustörés után a csípőtörés rizikója megduplázódik. A csontok mennyiségi, szerkezeti változása különösen jelentős a tárgyalt spongiosus csontok eseteiben a bekövetkező törések létrejöttében. A csonttörések létrejöttében az említett szerkezetváltozások mellett az elesések fontos szerepet játszanak és ebben a járás bizonytalansága, egyensúlyzavar, az izomerő csökkenése szerepel a csípőtörések és distalis radiustörések eseteiben. A kis traumára bekövetkező törésekre a legfontosabb jellemző a csontszilárdság csökkenése. Ilyenek például a proximalis humerus és distalis radiustörések. A csigolyatest törések ugyanakkor akár lényeges trauma nélkül is bekövetkezhetnek, s egy részük diagnosztizálatlan maradhat (44). Az osteoporosis talaján bekövetkező törések gyakran súlyosan károsíthatják az életminőséget. Így romló fiziológiai, fizikai és szociális következményekkel kell számolni. A csípőtáji törések krónikus fájdalmakkal, csökkent mobilitással, rokkantsággal társulnak. Az immobilitás és az ágyban töltött napok számának emelkedése csökkenti a napi aktivitást. Az osteoporosis talaján kialakult törések, főleg a csípőtáji, csigolyatest és felkarcsonttörések gyakran társulnak megnövekedett mortalitással.

Takács (44) szerint bár az osteoporosis kezelésének elsődleges célja a törés megelőzése, mégis a már törést elszenvedett betegek hatékony kezelése napjainkban a fö feladat. A törésen átesett betegeknek csak 20\%-a részesül hatékony osteoporosis ellenes kezelésben. A már törésen átesett betegek eseteiben fontos tényező az életmódváltozás, biztonságos környezet és a megfelelő D-vitamin- és kalciumpótlás. Magyarországon a D-vitamin szempontjából fokozott kockázatnak kitett egyéneknél egész évben javasolt a preventív célú D-vitamin-adás, míg az egészségeseknél csak a téli, kora-tavaszi hónapokban ajánlott (22). Lakatos és munkatársai szerint (20) a D-vitamin- és kalciumpótlás az osteoporosis bázisterápiájának tekinthető. Valószínű, hogy a napi 1000-1500 mg kalcium és a 800-1000 NE D-vitamin hatékonyan növeli a csonttömeget és csökkenti a törés kockázatát. $\mathrm{Az}$ I. táblázatban az idős emberek körében ajánlott napi $D_{3}$ és kalcium dózisok vannak feltüntetve, ebben hívjuk fel mindazon klinikai szituációra a figyelmet, amikor az egyéb társuló betegséget és a beteg étkezési szokásait is mérlegelni kell, különösen a kalcium 
mennyiségének meghatározása és a kalcium készítményének kiválasztása tekintetében. Erre vonatkozóan a részletek, korábbi közleményünkben (37) olvashatók.

A $75 \mathrm{nmol} / \mathrm{L}$ 25(OH)D szérumszint elérése a vonatkozó irodalmi adatok szerint elfogadott a törési rizikó csökkentésére, amit egyesek az említett D-vitamin-pótlással, mások a D-vitamin és kalcium együttes adásával végeznek. Az egymásnak néha ellentmondó irodalmi adatok, metaanalízisek eltérő véleményei adódhatnak abból is, hogy ezek a metaanalízisek nem térnek ki mindig a betegek életvitelbeli, táplálkozási szokásaira, a beválasztási kritériumok nem egységesek. Az egyéb klinikai állapotokat, az azzal összefüggő gyógyszereléseket sokszor figyelmen kívül hagyják. Különbségek állnak fenn a definíciókban, a 25(OH)D módszerek analitikájában, azok cutoff értékeiben, amelyekre a D-vitamin ellátottságot alapozzák. Logikus, ha a vizsgált csoportba jó D-vitamin ellátottságú is bekerült, akkor a hozzáadott $D_{3}$-vitamin hatása nem lesz kimutatható. Ugyanez érvényes a kalcium adására is, adagját csak akkor tudjuk definiálni, ha felmértük a betegünknél a tejtermék fogyasztási szokásait (37). A klinikai gyakorlat számára az osteoporosissal társuló törésesekkel kapcsolatos tennivalókat Boonen és munkatársai (7) az alábbiakban foglalják össze:

1.) Az osteoporosis olyan betegség, amely folyamatos orvosi ellenőrzést igényel a beteg optimális állapotának biztosításához.
2.) Megfelelő dózisú D-vitamint és kalciumot kell alkalmazni az osteoporoticus törések prevenciójában és kezelésében, ezt végzik az osteologiai szakellátás során.

3.) A D-vitamin és kalcium egy esszenciális, de nem elegendő komponens az olyan osteoporoticus betegek integrált kezelési stratégiájában, akik nem megfelelően táplálkoznak.

4.) A D-vitamin- és kalciumkezelés költséghatékonysággal jár.

5.) További útmutatások szükségesek és várhatók még ezen szerek optimális használatára. Jelentős problémát okoz az ilyen csonttöréseken átesett idős betegek további ellátása, sorsa. A kórházban eltöltött napok száma egyébként éves szinten nagyobb, mint a myocardialis infarctus, stroke, emlőrák, s egyes krónikus betegségek eseteiben, s mindez jelentős költségnövekedést jelent. Az ilyen betegek életminősége, járóképessége, önellátó képessége csökken, szociális helyzetük romlik (41).

A traumatológusok a korszerű szakmai irányelveknek megfelelően éjjel-nappal végzik a tárgyalt osteoporoticus törések korai mútéti ellátását. Fontos azonban, hogy a kemény igénybevétel mellett is tájékozódjanak az esetek többségében fennálló D-vitamin-hiányról, s szükség esetén végezzenek D-vitamin és kalciumpótlást és javasolják otthon is a fenti kezelés folytatását, illetve szükség esetén irányítsák a beteget az osteologiai szakrendelésre. Ezzel, munkájuk eredményesebb lesz, javítva az idős betegek életkilátását, és életminőségét. 


\section{IRODALOM}

1. Avanell A., Gillespie W., Gillespie L., O,Connell D.: Vitamin D and vitamin D analogues for preventing fractures associated with involutional and post menopausal osteoporosis. Cochrane Syst. Rev. 2009. Apr 15; (2): CD000227. https://doi.org/10.1002/14651858.cd000227.pub3

2. Bhattoa H. P., Nagy E., More C., Kappelmayer A., Balogh A., Kalina E., Antal-Szalmas P.: Prevalence seasonal variation of hypovitaminosis $D$ and its relationship to bone metabolism in healthy Hungarian men over 50 years of age: the HumMen Study. Osteoporos. Int. 2013. 24. (1): 179-186. https://doi.org/10.1007/s00198-012-1920-2

3. Bischoff-Ferrari H. A., Willett W. C., Orav E. J., Lips P. L., Meunier P. J., Lyons R. A., Flicker L., Wark J., Jackson R. D., Cauley J. A., Meyer H. E., Pfeifer M., Sanders K. M., Stähelin H. B., Theiler R., Dawson-Hughes B.: A pooled analysis of vitamin D dose requirements for fracture prevention. N. Engl. J. Med. 2012. 367. (1): 40-49. https://doi.org/10.1056/nejmoa1109617

4. Bischoff-Ferrari H., Dawson Hughes B., Orav E. J., Staehelin H. B., Meyer O. W., Theiler R., Dick W., Willett W. C., Egli A.: Monthly high-dose vitamin $D$ treatment for the prevention of functional decline: A randomized clinical trial. JAMA Int. Med. 2016. 176. (2): 175-183. https://doi.org/10.1001/jamainternmed.2015.7148

5. Bischoff-Ferrari H.: Vitamin D: what is an adequate vitamin D level and how much supplementation is necessery? Best Pract. Res. Clin. Rheumatol. 2009. 23. (6): 789-795. https://doi.org/10.1016/i.berh.2009.09.005

6. Bolland M. J., Grey A., Gamble C., Reid I. R.: Vitamin D supplementation and falls. A trial sequential meta-analysis. Lancet Diabetes Endocrinol. 2014. 2. (7): 573-580. https://doi.org/10.1016/s2213-8587(14)70068-3

7. Boonen S., Rizzoli R., Meunier P. J., Stone M., Nuki G., Syversen U., Lehtonen-Veromaa M., Lips P., Johnell O., Reginster J. V.: The need for clincal guidance in the use of calcium and vitamin D in the management of osteoporosis: a consensus report. Osteoporos. Int. 2004. 15. (7): 511-519. https://doi.org/10.1007/s00198-004-1621-6

8. Buchebner D., McGuigan F., Gerdheim P., Malm J., Ridderstråle M., Akesson K.: Vitamin D insufficiency over 5 years is associated with increased fracture risk-an observational cohort study of elderly women. Osteoporos. Int. 2014. 25. (12): 2767-2775. https://doi.org/10.1007/s00198-014-2823-1

9. Di Monaco M., Vallero F., Di Monaco R., Mautino F., Cavanna A.: Serum levels of 25 -Hydroxyvitamin D and functional recovery after hip fracture. Arch. Phys. Med. Rehabil. 2005. 86. (1): 64-68. https://doi.org/10.1016/i.apmr.2004.02.013

10. Doetsch A. M., Faber J., Lynnerup N., Wätjen I., Bliddal H., Denneskiold-Samsoe B.: The effect of calcium and vitamin D3 supplementation on the healing of the proximal humerus fracture: a randomized placebo-controlled study. Calcif. Tissue Int. 2004. 75. (1): 183-188. https://doi.org/10.1007/s00223-004-0167-0

11. Dorner T., Weichselbaum E., Lawrence K., Stein K.V., Rieder A.: Austrian osteoporosis report: epidemiology, lyfestyle, factors, public health strategies. Wien Med. Wochenschr. 2009. 159. (9-10): 221-229. https://doi.org/10.1007/s10354009-0649-9

12. Dua M., Sharma J., Neema P. P.: Evaluation of role of vitamin D in grip strength in post-menopausal women with fracture of distal end radius treated with closed reduction and percutaneus K-wire fixation. Ind. J. Orthop. Surg. 2016. 2. (1): 110-114. https://doi.org/10.5958/2395-1362.2016.00021.9

13. Fischer V., Haffner-Luntzer M., Amling M., Ignatius A.: Calcium and Vitamin D in bone fracture healing and post-traumatic bone turnover. Eur. Cell Mater. 2018. 35: 365-385. https://doi.org/10.22203/ecm.v035a25

14. Flóris I., Belicza É.: A csípötáji törések hazai ellátásának elemzése a 2004-2009 közötti időszakban. Orv. Hetil. 2016. 157. (41): 1642-1648. https://doi.org/10.1556/650.2016.30560

15. Folman Y., Gepstein R., Assaraf A., Liberty S.: Functional recovery after operative treatment of femoral neck fractures in a institutionalized elderly population. Arch. Phys. Med. Rehab. 1994. 75. (4): 454-456. https://doi.org/10.1016/0003-9993(94)90171-6

16. Gomez-de-Tehada M. J., Navarro Rodrigez M. C., Saavedra Santana P., Quesada Gomez J. M., Gimeno E. J., Henriquez M. S.: Prevalence of osteoporosis, vertebral fractures and hypovitaminosis $D$ in postmenopausal women living in a rural environment. Maturitas. 2014. 77. (3): 282-286. https://doi.org/10.1016/i.maturitas.2013.12.011

17. Hernandez J. L., Olmos J. M., Pariente E., Nan D., Martinez J., Llorca J., Valero C., Obregón E., Gonzales.: Influence of vitamin $D$ status on vertebral fractures, bone mineral density, and bone turnover markers in normocalcemic postmenopausal women with high parathyroid hormone levels. J. Clin. Endocrinol. Metab. 2013. 98. (4): $1711-1717$. https://doi.org/10.1210/ic.2012-3931

18. Jang W. Y., Chung M. S., Baek G. H., Song C. H., Cho H. E., Gong H. S.: Vitamin D levels in post-menopausal Korean women with a distal radius fracture. Injury, 2012. 43. (2): 237-241. https://doi.org/10.1016/i.injury.2011.10.020

19. Johnell O., Kanis J. A.: An estemate of the worldwide prevalence and disability associated with osteoporotic fractures. Osteoporos. Int. 2006. 17. (12): 1726-1733. https://doi.org/10.1007/s00198-006-0172-4

20. Lakatos P., Takács I.: A D vitaminhiány gyakorisága és népegészségügyi jelentősége. Magyar Orvos. 2014. 22. (1): 19.

21. Lakatos P., Tóth E., Szekeres L., Poór G, Marton I., Takács I.: Comparative statistical analysis of osteoporosis treatment based on Hungarian claims data and interpretation of the results in respect to cost-effectivenes. Osteoporos. Int. 2014. 25. (8): 2077-2087. https://doi.org/10.1007/s00198-014-2733-2

22. Le Boff M. S., Kohlmeier L., Hurwitz S., Franklin J., Wright J., Glowacki J.: Occult vitamin D deficiency in postmenopausal US women with acute hip fracture. JAMA. 1999. 281. (16): 1505-1511. https://doi.org/10.1001/jama.281.16.1505

23. Lv Q. B., Gao X., Liu X., Shao Z. X., Xu Q. H., Tang L., Chi Y. L., Wu A. M.: The serum 25-hydroxyvitamin D levels and hip fracture risk: a meta-analysis of prospective cohort studies. Oncotarget. 2017. 8. (24): 39849-39858. https://doi.org/10.18632/oncotarget.16337 
24. Maier G., Seeger J. B., Horas K., Roth K. E., Maus U.: The prevalence of vitamin D deficiency in patients with vertebral fragility fractures. Bone Joint J. 2015. 97-B. (1): 89-93. https://doi.org/10.1302/0301-620x.97b1.34558

25. Mészáros Sz.: A csonttörési kockázat felismerése. A csontanyagcsere betegségei. Szerk.: Lakatos P., Takács I. Budapest, Semmelweis Kiadó, 2012. 519. $p$.

26. MOOT vezetösége, Osteoporosis (csontritkulás) az adatok tükrében. Sajtóközlemény, 2011.08.01.

27. Murad M. H., Elamin K. B., Elnour N. O. A., Elamin M. B., Alkatib A. A., Fatourechi M. M., Almandoz J. P., Mullan R. J., Lane M. A., Liu H., Erwin P. J., Hensrud D. D., Montori V.. M.: Clinical review: The effect of vitamin D and falls: A systematic review and meta-analysis. J. Clin. Endocrinol. Metab. 2011. 96. (10): 2997-3006. https://doi.org/10.1210/jc.2011-1193

28. Ohta H., Uemura Y., Nakamura T., Fukunaga M., Ohasi Y., Hosoi T., Mori S., Sugimoto T, Itpi E., Orimo H., Shiraki M.: Serum 25-hydroxyvitamin D leve las an independent determination of quality of life in osteoporosis with high risk for fracture. Clin. Ther. 2014. 36. (2): 225-235. https://doi.org/10.1016/i.clinthera.2013.12.007

29. Oven J., Apalset E. M., Glesdal C. G., Brudvik C., Lie S. A., Hove L. M.: Vitamin D inadquancy is associated with low energy distal radius fractures: a case.control study. Bone. 2011. 48. (5): 1140-1145. https://doi.org/10.1016/j.bone.2011.01.021

30. Parfitt A. M., Gallagher J. C., Heaney R. P., Johnston C. C., Neer R., Whedon G.. D.: Vitamin D and bone health in the elderly. Am. Soc. Clin. Nutr. 1982. 36. (5 Suppl): 1014-1031. https://doi.org/10.1093/ajcn/36.5.1014

31. Péntek M., Horváth C., Boncz I., Falusi Z., Tóth E., Sebestyén A., Májer I., Brodszky V., Gulácsi I.: Epidemiology of osteoporosis related fractures in Hungary from the nationwide health insurance database, 1999-2003. Osteoporos. Int. 2008. 19. (2): 243-249. https://doi.org/10.1007/s00198-007-0453-6

32. Poole C. D., Smith J. C., Davis J. S.: The short-term impact of vitamin D-based hip fracture prevencion in older adults in the United Kingdom. J. Endocrinol. Invest. 2014. 37. (9): 811-817. https://doi.org/10.1007/s40618-014-0109-2

33. Ringe J. D.: The effect of vitamin D on falls and fractures. Scand. J. Clin. Lab. Invest. Suppl. 2012. 243: 73-78.

34. Rozental T. D., Herder L. M., Kempland C., Walley K. C., Zurakowski D., Coyle K., Bouxsein M. L., WolfJ. M.: Hydroxyvitamin-D and bone turnover marker levels in patients with distal radial fracture. J. Bone Joint Surg. Am. 2015. 97. (20): 1685-1693. https://doi.org/10.2106/ibjs.0.00313

35. Salamon A., Biró Cs., Toldy E.: A D vitamin-hiány szerepe az elesések és csonttörések patogenezisében. Orv Hetil. 2013. 154 19: 731-736.

36. Salamon A., Hepp B., Mátrai Á., Biró Cs., Ágota K., Fata E., Löcsei Z., Toldy E.: A csípötáji csonttörést szenvedett betegek D vitamin ellátottsága. Orv. Hetil. 2014. 155.17: 659-668. https://doi.org/10.1556/oh.2014.29878

37. Salamon A., Toldy E., Biró Cs., Mátrai Á., Balassa T., Lőcsei Z.: D-vitamin és kalciumpótlás az időskori csípőtáji törések megelözésében. Orv. Hetil. 2017. 156. (43): 1699-1707. https://doi.org/10.1556/650.2017.30892

38. Schilling S.: Epidemic vitamin D deficiency among patients in an elderly care rehabilitation facility. Dsch. Arztebl. Int. 2012. 109. (3): 33-38. https://doi.org/10.3238/arztebl.2012.0033

39. Sebestyén A., Boncz I., Tóth F., Péntek M., Nyárádi J., Sándor J.: Időskori combnyaktöréseket követő halálozás és kockázati tényezőik kapcsolatának értékelése 5 éves utánkövetéssel. Orv. Hetil. 2008. 149 (11): 493-503.

40. Sebestyén A., Somogyi P.: Az osteoporosis epidemiológiája. In: A Csontanyagcsere betegségei. Szerk: Lakatos P., Takács I. Budapest, Semmelweis Kiadó, 174-180. p.

41. Somogyi P., Kricsfalusy M., Gaál J., Cserháti P.: Csípötáji törések jelentősége a magyarországi adatok tükrében. Osteológiai Közlemények. 2010. 18. (2). 67-72.

42. Szekeres L., Takács I.: A D vitamin hatása a csontvázra. Orvostovábbképzö Szemle. 2016. 23. 2. ksz. $15-16$.

43. Tahririan M. A., Motififard M., Omidian A., Hossein M. D., Aghdam A., Esmaeli A.: Relationship between bone mineral density and serum vitamin D radius fractures. Arch. Bone Joint Surg. 2017. 5. (1): 22-27.

44. Takács I., Bittner N.,Bakos B., Benkö I., Dank M., Horváth V., Salamon A., Szabó B., Szekeres L., Szili B., Sziller I., Toldy E., Valkusz Zs., Várbíró Sz., Bodolay E., Kovács T. Szabó A., Wikonkál N., Lakatos E.: Harmadik magyarországi konszenzus a D vitamin szerepéröl a betegségek megelözésében és kezelésében. Orvostovábbképző Szemle. 2016. 23. 2. ksz. 13-26.

45. Takács I.: Törést szenvedett csontritkulásos betegek hosszú távú kezelésének aktuális szempontjai. Orvostovábbképző szemle. 2016. 23. 2. ksz. 37-43.

46. Thacher T. D., Clarke B. L.: Vitamin D Insufficiency. Mayo Clin. Proc. 2011. 86. (1): 50-60.

47. Thaler H. W., Oudshoorn C., Hartholt K. A., Cammen T. J. M.: Parameters of bone health and fracture risk in older female fall victims: what do they tell us? Z. Gerontol. Geriatr. 2015. 48. (6): 539-542. https://doi.org/10.1007/s00391-014-0843-2

48. Todd C. J., Freeman C. J., Camilleri-Ferrante C., Palmer C. R. Laxton C. E., Parker M. J., Payne B. V., Rushton N.: Diuffereces in mortality after fracture of hip: the east Anglian audit. BMJ. 1995. 310. (6984): 904-908. https://doi.org/10.1136/bmj.310.6984.904

49. Toldy E., Salamon A., Kálmán B., Ágota K., Horváth D., Lőcsei Z.: Prognostic relevance of circulating 25(OH)D fractions for early recovery in patients with hip fracture. J. Clin. Med. 2018. 7. (8): E193. https://doi.org/10.3390/icm7080193

\section{Prof. Dr. Salamon Antal}

9700 Szombathely, Király u. 11. II/10.

E-mail: salamon.antal@chello.hu

Mobil: +36 307428833 